\title{
Neurofibromatous neuropathy in neurofibromatosis 1 (NF1)
}

\author{
R E Ferner, R A C Hughes, S M Hall, M Upadhyaya, M R Johnson
}

J Med Genet 2004;41:837-841. doi: 10.1136/jmg.2004.021683

\begin{abstract}
Background: Neurofibromatosis 1 (NF1) is a common, autosomal dominant, neurocutaneous disease that is clinically and genetically distinct from the rare condition neurofibromatosis 2 (NF2). Neurofibromatous neuropathy has been regarded as a common feature of NF2, but is an unusual and unexplained complication of NF1. The clinical and histological features of the NF1 neuropathy are distinct from those encountered in NF2. We describe eight patients with a symmetrical polyneuropathy, which has been called neurofibromatous neuropathy

Methods: Clinical assessments, laboratory investigations, neuroimaging, and neurophysiology were undertaken in eight individuals with neurofibromatous neuropathy. None were referred because of neuropathic symptoms. Two subjects underwent sural nerve biopsy and three agreed to mutational analysis.

Results: The patients had an indolent symmetrical predominantly sensory axonal neuropathy and unusually early development of large numbers of neurofibromas. The biopsied nerves showed diffuse neurofibromatous change and disruption of the perineurium. Two patients developed a high grade malignant peripheral nerve sheath tumour. Disease causing mutations were detected in two individuals and molecular studies did not reveal any whole gene deletions.

Conclusions: Neurofibromatous neuropathy occurred in $1.3 \%$ of 600 patients with NF1. Its cause may be a diffuse neuropathic process arising from inappropriate signalling between Schwann cells, fibroblasts, and perineurial cells.
\end{abstract}

$\mathrm{N}$ eurofibromatosis $\mathrm{l}$ (NF1) is a common, autosomal dominant, neurocutaneous disease. ${ }^{1}$ There is wide variety of disease expression in patients with NFl and its numerous complications involve many of the body systems. The neurological manifestations may arise from tumours and malformations of the nervous system, deformities of the skull and skeleton, or pressure by neurofibromas on the peripheral nerves, spinal nerve roots, and spinal cord. ${ }^{2}$ Neurofibromatous neuropathy has been reported as a rare manifestation and is characterised by a distal sensorimotor neuropathy associated with diffuse neurofibromatous change in thickened peripheral nerves. ${ }^{3}$ Until the last decade, the genetic and clinical distinction between NFl and neurofibromatosis NF2 (NF2) was not always clearly established. ${ }^{4}$ In retrospect, the majority of cases of neuropathy and neurofibromatosis reported in the literature have been associated with NF2. ${ }^{35-8} \mathrm{NF} 2$ neurofibromatous neuropathy is entirely different clinically and histologically from NFl associated neurofibromatous neuropathy. ${ }^{8}$

In this paper we describe eight patients with NFl and neurofibromatous neuropathy, which is the largest group of cases so far reported. The patients all attend our multidisciplinary neurocutaneous clinic comprising 600 NF1 patients, suggesting that this complication of NFl may not be as rare as previously supposed, although it still only affects $1.3 \%$ of patients. ${ }^{3}$ We describe the clinical and neurophysiological features in all our patients, the nerve biopsy appearances in two, and the causative NFI mutation in a further two of the three patients who agreed to mutation testing.

\section{METHODS}

The eight patients consist of all those patients with NFl who also had a symmetrical polyneuropathy and who had been referred to the Guy's Hospital multidisciplinary Neurocutaneous Clinic for general assessment of neurofibromatosis 1, between 1985 and 2003. ${ }^{9}$ During this period 600 patients with NF1 were assessed clinically. Ethical approval was obtained for the study. General medical and neurological assessments were performed on all patients and nerve conduction studies were undertaken on all patients with symptoms or signs of a peripheral neuropathy. Magnetic resonance imaging of the spine was performed on seven patients with a $1.5 \mathrm{~T}$ superconducting system (Philips Gyroscan S15, Philips Medical Systems). Images were taken in the axial and coronal planes with a slice thickness of $5 \mathrm{~mm}$ and an interscan distance of $0.5 \mathrm{~mm}$. Coronal STIR images (TR/TE 2000/25, TI 150) were performed and axial Tl images (TR/TE 700/20) were carried out before and following the administration of gadolinium meglumine triamine pentacetic acid contrast medium at $0.2 \mathrm{ml} / \mathrm{kg}$.

\section{Sural nerve biopsy}

Two patients underwent sural nerve biopsy for the purpose of diagnosis. Portions of the nerve were processed into paraffin and also into epon for $1 \mu \mathrm{m}$ sections stained with thionin and acridine orange and ultrathin sections for electron microscopy as previously described. ${ }^{10}$

\section{Mutational analysis}

Three patients agreed to donate blood for mutation analysis. Mutation analysis was performed using a combination of chemical cleavage of mismatch, single strand conformational analysis, and direct sequencing. DNA samples from 70 nonNFl patients were used as controls. Haploinsufficiency was excluded at the genomic and mRNA level prior to mutation analysis with chemical cleavage of mismatch, by demonstration of heterozygosity at exon 5 (Rsal polymorphism) in genomic DNA and cDNA, respectively.

\section{Laboratory investigations}

The following investigations were carried out: haemoglobin, erythrocyte sedimentation rate, serum folate, vitamin B12, urea, creatinine and electrolytes, liver function, blood

Abbreviations: GRD, guanosine triphosphatase related domain; MPNST, malignant peripheral nerve sheath tumour; NF1, neurofibromatosis 1; NF2, neurofibromatosis 1 


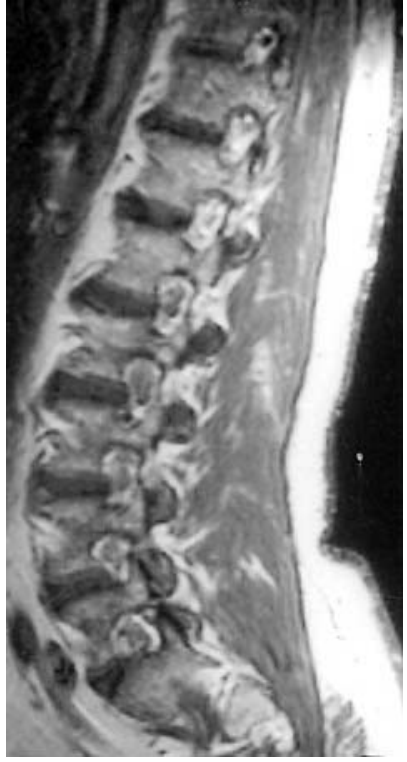

Figure 1 Patient 1 (see table 1) TI weighted MRI of the lumbar spine with gadolinium meglumine triamine pentacetic acid contrast. Neurofibromas involve all the nerve roots but do not cause cord compression.

glucose, autoantibodies, serum immunoglobulins, protein electrophoresis, thyroid function, and treponema pallidum microhaemagglutination assay.

\section{RESULTS}

The clinical, radiological, and neurophysiological features of all the cases are reported in tables $1-3$ and illustrated in figs 1 and 2. The laboratory investigations mentioned for known causes of neuropathy were normal in all patients. The neurophysiological features were those of a predominantly sensory, length dependent axonal neuropathy with abnormally small sural nerve sensory action potentials, relatively normal median nerve sensory action potentials, slightly delayed distal motor conduction and $\mathrm{F}$ wave latencies, and slightly slowed motor nerve conduction velocities (table 3 ).

\section{Nerve biopsy}

\section{Patient 1}

A sural nerve biopsy showed non-uniform pathological changes. Some fascicles displayed a marked loss of axons of all calibres, whereas in others the axonal drop out was mild and confined to a sub-perineurial zone. There was little evidence of ongoing active degeneration in any fascicle. Regions of focal perineurial disruption, associated with a hypercellular epineurium and disorganised sub-perineurium, were prominent features of fascicles that displayed the most marked axonal loss. At these sites, the sub-perineurial endoneurium was filled with bundles of collagen and numerous process bearing cells, none of which were associated with axons. On morphological criteria, these cells were identified as either chronically denervated Schwann cells ${ }^{11}$ or perineurial cells, whose long cytoplasmic processes were associated with continuous or patchy basal laminae, and were studded with caveolae, or fibroblasts (fig 3). Schwann cell-ensheathed axons, both myelinated and nonmyelinated, were present between the discontinuous perineurial layers, sometimes associated with reduplicated fragments of basal lamina and fibrous long spacing collagen. Perineurial cells and fibroblasts (the latter occasionally surrounding collagen pockets) filled the inter-fascicular epineurium (fig 4). Mast cells were present, often close to a blood vessel, within the epineurium and endoneurium.

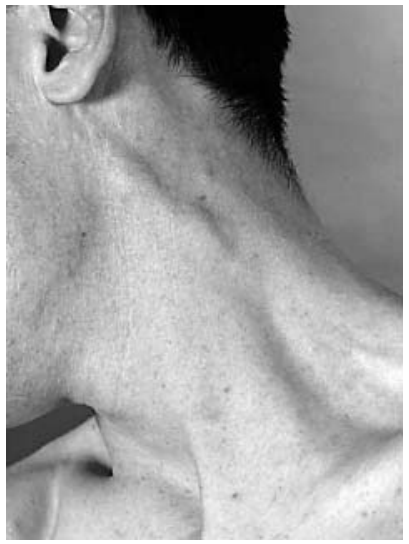

Figure 2 Patient 4 (see table 2). Thickened greater auricular nerve.

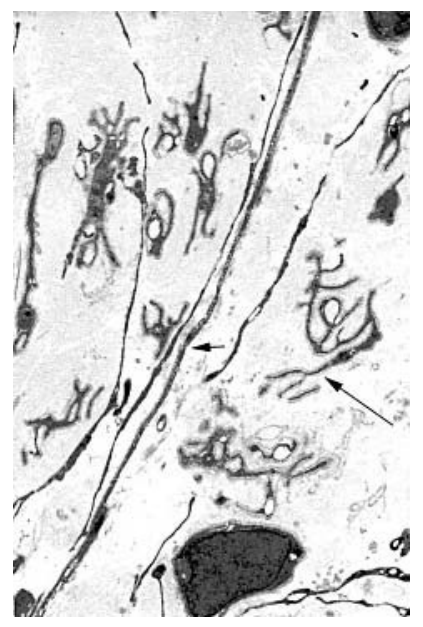

Figure 3 Patient 1. Transverse resin section, electron microscopy. A number of delicate cytoplasmic processes are embedded in a collagenous matrix in the subperineurial zone. Branched profiles surrounded by a basal lamina display the typical morphology of denervated Schwann cells (long arrow). The unbranched processes bearing caveolae and associated with patches of basal lamina are perineurial cells (short arrow), and the fine dense processes that bear neither caveolae nor basal laminae are probably fibroblasts. $\times 1500$.

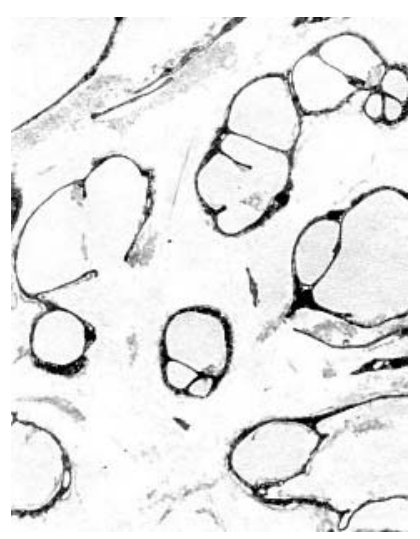

Figure 4 Patient 1. Transverse resin section, electron microscopy. Delicate cytoplasmic processes studded with caveolae and often associated with a fragmentary basal lamina, lie in a collagenous matrix in the epineurium between two fascicles. Some of the processes surround collagen in typical collagen pockets. $\times 2500$.

\section{Patient 3}

A right partial thickness sural nerve biopsy of five fascicles showed a significant reduction of myelinated nerve fibres and an increased number of fibroblast-like cells within the fascicles. Some of the axons were thinly myelinated and associated with unmyelinated axons in structures resembling onion bulbs, and many persisting axons were small and unmyelinated.

\section{Mutation analysis}

Molecular studies did not detect a whole-gene deletion in any of the patients tested. 


\begin{tabular}{|c|c|c|c|c|}
\hline $\begin{array}{l}\text { Patient } \\
\text { no. }\end{array}$ & $\begin{array}{l}\text { Age at last } \\
\text { examination } \\
\text { (years) }\end{array}$ & $\begin{array}{l}\text { Age of } \\
\text { neuropathy } \\
\text { onset (years) }\end{array}$ & Additional clinical problems & $\begin{array}{l}\text { Presence of multiple spinal nerve } \\
\text { root neurofibromas } \\
\text { on MRI }\end{array}$ \\
\hline 1 & 53 & 42 & $\begin{array}{l}\text { High grade MPNST left iliac fossa removed in 1986. No } \\
\text { recurrence. Benign plexiform neurofibroma left abdominal wall }\end{array}$ & Yes (fig 1) \\
\hline 2 & 27 & 17 & $\begin{array}{l}\text { Congenital adrenal } 21 \text {-hydoxylase deficiency. Cervical } \\
\text { intradural neurofibromas removed at age } 22 \text {. Massive } \\
\text { inoperable pelvic neurofibromas }\end{array}$ & Yes \\
\hline 3 & 26 & Infancy & Complex partial seizures since childhood & Yes \\
\hline 4 & 31 & 27 & Mild cognitive impairment. Brachial plexus neurofibromas & Yes \\
\hline 5 & 48 & 47 & Cognitive impairment & Yes \\
\hline 6 & 19 & 3 & Left sciatic plexiform neurofibroma & No, only lumbar spine scanned \\
\hline 7 & 62 & 55 & $\begin{array}{l}\text { Bony dysplasia of spine and clavicle. Plexiform neurofibroma } \\
\text { involving neck, anterior chest wall, left arm. Died from chronic } \\
\text { obstructive airways disease at age } 62\end{array}$ & No \\
\hline 8 & 45 & 25 & $\begin{array}{l}\text { Benign neurofibromas removed from right } L 4 \text { and } L 5 \text { nerve } \\
\text { roots at age } 33 \text {. High grade MPNST left sciatic nerve } \\
\text { removed at age } 44 \text {. Died from lung metastases at age } 45\end{array}$ & $\begin{array}{l}\text { Yes on myelogram; MRI not } \\
\text { performed }\end{array}$ \\
\hline
\end{tabular}

Patient 1

Mutation analysis detected a novel mutation in exon 23.2 of the $N F 1$ gene. This alteration involved the deletion of cytosine at position 4071, which resulted in a premature stop codon. The deletion is predicted to generate a truncated neurofibromin of 1383 amino acids.

\section{Patient 3}

Mutation analysis revealed a substitution of leucine to proline at codon 1243 (CTG to CCG). This change results in the introduction of a non-aliphatic amino acid group into the NFl guanosine triphosphatase related domain (GRD) of the peptide. Such a change is likely to disrupt the structure of the GRD and to be a disease causing mutation.

\section{Patient 4}

Mutation analysis failed to detect the mutation in this patient.

\section{DISCUSSION}

Of our 600 NFl patients, eight had neurofibromatous neuropathy. None was initially referred because of symptoms relating to their neuropathy. Consequently, this condition might be under-diagnosed because sensory symptoms might be incorrectly attributed to cutaneous or subcutaneous neurofibromas. The presence of peripheral neuropathy may be revealed by a detailed examination of the nervous system.

There was a variable age of onset of neuropathic symptoms, but we noted a distinctive clinical phenotype, characterised by unusually early development of dermal and subcutaneous neurofibromas, occurring in large numbers and affecting extensive areas of the body. In six of the eight cases we detected neurofibromas arising proximally from multiple nerve roots in the spine. In our experience spinal nerve root neurofibromas are common in NFl but do not usually cause neuropathic symptoms or signs. In our patients the neuropathic symptoms were predominantly mild and sensory. Only one patient required treatment with a

Table 2 Clinical manifestations of neurofibromatous neuropathy in eight individuals with neurofibromatosis 1

\begin{tabular}{|c|c|c|c|c|c|c|}
\hline $\begin{array}{l}\text { Patient } \\
\text { no. }\end{array}$ & $\begin{array}{l}\text { First neuropathic } \\
\text { symptom }\end{array}$ & Weakness & Sensory impairment & Reflexes & $\begin{array}{l}\text { Diffuse } \\
\text { nerve } \\
\text { thickening }\end{array}$ & $\begin{array}{l}\text { Disability } \\
\text { Rankin } \\
\text { Scale }\end{array}$ \\
\hline 1 & $\begin{array}{l}\text { Numbness and } \\
\text { tingling in hands } \\
\text { and aching } \\
\text { in feet }\end{array}$ & None & $\begin{array}{l}\text { Impairment of light touch and pain up to } \\
\text { elbows and to right knee and left mid-calf. } \\
\text { Impaired vibration at right hallux and } \\
\text { left ankle }\end{array}$ & Reduced & Present & $1^{30}$ \\
\hline 2 & $\begin{array}{l}\text { Pain and } \\
\text { weakness } \\
\text { in feet }\end{array}$ & $\begin{array}{l}\text { Distally predominant weakness } \\
\text { and wasting of } \\
\text { upper and lower limbs }\end{array}$ & $\begin{array}{l}\text { Severe impairment of all modalities up to } \\
\text { elbows and inguinal ligament }\end{array}$ & Absent & Present & 4 \\
\hline 3 & Pes cavus & Weakness of toe flexion & Impaired vibration sensation on toes & $\begin{array}{l}\text { Absent ankle } \\
\text { reflexes }\end{array}$ & Present & 1 \\
\hline 4 & No symptoms & None & $\begin{array}{l}\text { Mild impairment of pain on fingers and feet } \\
\text { and light touch on toes }\end{array}$ & Normal & $\begin{array}{l}\text { Marked } \\
\text { (fig 2) }\end{array}$ & 0 \\
\hline 5 & $\begin{array}{l}\text { Numbness and } \\
\text { tingling in hands } \\
\text { and feet }\end{array}$ & $\begin{array}{l}\text { Weakness of interossei and } \\
\text { ankle dorsiflexion }\end{array}$ & $\begin{array}{l}\text { Light touch, vibration, and pinprick sensation } \\
\text { reduced to the ankles and vibration sensation } \\
\text { on the fingers }\end{array}$ & $\begin{array}{l}\text { Reduced } \\
\text { ankle } \\
\text { reflexes }\end{array}$ & Present & 1 \\
\hline 6 & Pes cavus & $\begin{array}{l}\text { Mild weakness of dorsal interossei, } \\
\text { left ankle dorsiflexion, left toe } \\
\text { dorsiflexion, plantar flexion* }\end{array}$ & $\begin{array}{l}\text { Impaired pinprick sensation in glove and } \\
\text { stocking distribution up to the } \\
\text { mid-forearms and mid-shins }\end{array}$ & Present & Absent & 1 \\
\hline 7 & $\begin{array}{l}\text { Tingling and } \\
\text { numbness in feet }\end{array}$ & None & $\begin{array}{l}\text { Impaired light touch and pain to mid-palms, } \\
\text { the left thigh, and the right forefoot. Absent } \\
\text { vibration in lower limbs }\end{array}$ & Present & Absent & 1 \\
\hline 8 & $\begin{array}{l}\text { Pes cavus, } \\
\text { weakness } \\
\text { in legs }\end{array}$ & $\begin{array}{l}\text { Wasted anterior compartments } \\
\text { bilaterally. Bilateral weakness of } \\
\text { hip flexion, knee extension, } \\
\text { ankle dorsiflexion, plantar } \\
\text { flexion, inversion, eversion }\end{array}$ & $\begin{array}{l}\text { Loss of pain sensation below both knees. } \\
\text { Reduced vibration sense at the ankles. } \\
\text { Reduced joint position sense } \\
\text { at the hallux bilaterally }\end{array}$ & $\begin{array}{l}\text { Absent } \\
\text { ankle } \\
\text { jerks }\end{array}$ & $\begin{array}{l}\text { Not } \\
\text { recorded }\end{array}$ & 4 \\
\hline
\end{tabular}


Table 3 Electrophysiological features in eight individuals with neurofibromatosis 1 and neurofibromatous neuropathy

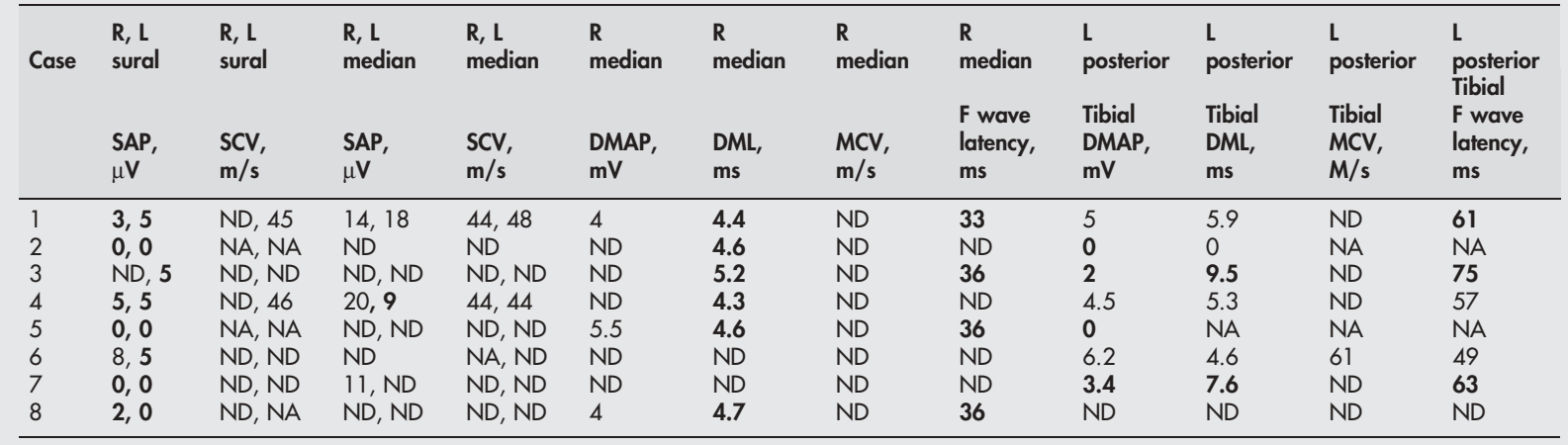

DMAP, distally evoked compound muscle action potential; DML, distal motor latency; MCV, maximal motor conduction velocity; NA, not available; ND, not done; SAP, sensory action potential; SCV, sensory conduction velocity.

Abnormal figures are given in bold.

combination of gabapentin and amitriptyline for neuropathic pain. The patients were followed up for between 1 and 10 years and there was no evidence of significant clinical or neurophysiological deterioration of the neurofibromatous neuropathy. This is in contradistinction to neuropathy in NF2 where there is variable disease progression. Patients 1 and 8 developed a high grade MPNST, which occurs with increased frequency in patients with NFl and plexiform neurofibromas and often carries a poor prognosis. ${ }^{12}$ It remains to be determined whether patients with early development of large numbers of neurofibromas and neurofibromatous neuropathy are at higher risk of malignant change.

We have identified disease causing mutations in patients 1 and 3. Molecular studies did not reveal any whole-gene deletions. A disease causing mutation was not detected in patient 4. All of our eight patients had NFl as a new mutation and we are unable to assess the effect of familial aggregation of neurofibromatous neuropathy in NF1. In our patients neurofibromatous neuropathy was not associated with any particular genotype, which may be explained by influence from unidentified modifying genes. ${ }^{13}$ We (MU) have detected a mutation identical to that in patient 1 in another individual with NFl who, however, does not have clinical manifestations of a peripheral neuropathy and has normal nerve conduction studies. Undoubtedly, a larger molecular study would be helpful in determining the mutational spectrum of NFl neurofibromatous neuropathy.

We confirm the previous histological report of neurofibromatous neuropathy in NFl. ${ }^{3}$ Neurofibromas contain a mixture of Schwann cells (up to $80 \%$ ), fibroblasts, perineurial cells, and axons ${ }^{14-17}$ lying within a collagen-rich extracellular matrix. The perineurial disruption we have described is entirely consistent with a failure to initiate and/or maintain appropriate cell-cell signalling between Schwann cells, fibroblasts, and perineurial cells, and accords with previous findings that Schwann cells and fibroblasts are abnormal in NFl associated neurofibromas. ${ }^{18-22}$ The interdependence of axons and their associated Schwann cells is well established, ${ }^{23} 24$ whereas relatively little is known about the interactions that occur between Schwann cells, fibroblasts, and perineurial cells. ${ }^{25}{ }^{26}$ However, there is now compelling evidence that Schwann cell derived desert hedgehog plays a significant role in perineurial differentiation and fascicle formation. ${ }^{27} 28$ It is therefore of interest that a paracrine hedgehog signalling pathway has been implicated in the formation of neurofibromas in NFl. ${ }^{29}$

The clinical and neurophysiological features in all our eight patients were of an indolent length dependent sensorimotor neuropathy with predominantly sensory signs. It was painless in seven out of eight patients. These features and the nerve biopsy findings indicate diffuse affection of peripheral nerve function. Neurofibromatous neuropathy is probably more common than previously thought since the symptoms were not prominent and detailed neurological examination was sometimes necessary to detect the clinical deficits. It has to be distinguished from the cumulative effects of multiple neurofibromas on spinal roots, nerve trunks, and peripheral nerves. We have evaluated all of our $600 \mathrm{NFl}$ patients for symptoms and clinical signs of neuropathy. Of these, seven (age range 29-35 years) had symptoms of tingling and numbness but the nerve conduction studies were all normal. Two of them had thickened spinal nerve roots. We are confident that clinical manifestations in our series are not more frequent than we have described, but we cannot exclude the possibility that subclinical peripheral neuropathy is more common. Our findings indicate that patients with peripheral neuropathy should be examined for evidence of peripheral neuropathy. If found, neurophysiological studies should be performed and other possible, often treatable, causes of peripheral neuropathy should be sought. In their absence a diagnosis of neurofibromatous neuropathy can then be made, often without resort to a peripheral nerve biopsy. Further research is needed to confirm that neurofibromatous neuropathy is associated with plexiform neurofibromas and an increased risk of developing MPNSTs. Further research is also needed to elucidate the contribution of the NFI mutation and individual cell types to the diffuse neurofibromatous change in peripheral nerves which characterises neurofibromatous neuropathy.

\section{ACKNOWLEDGEMENTS}

We are very grateful to Dr Peter Payan and Professor Kerry Mills from the Department of Neurology, Guy's Hospital, London, for performing nerve conduction studies on our patients. We acknowledge the late Dr John Bingham and Dr Wajanat Jan from the Department of Radiological Sciences at Guy's and St. Thomas' Hospitals, for reporting the magnetic resonance imaging. We thank Dr Nancy Ratner from the Department of Cell Biology, Neurobiology and Anatomy, University of Cincinnati College of Medicine, OH, USA for her advice. MU is grateful to Mike Osborn for technical support and to Dr Splitt for clinical information.

\section{Authors' affiliations}

R E Ferner, R A C Hughes, Department of Clinical Neurosciences, Guy's, Kings and St. Thomas' School of Medicine, London, UK

S M Hall, Centre for Neuroscience Research, Guy's, Kings and St. Thomas' School of Biomedical Sciences, London, UK

M Upadhyaya, Institute of Medical Genetics, University of Wales College of Medicine, Cardiff, UK 
M R Johnson, Division of Neurosciences, Charing Cross Hospital, London, UK

Conflict of interest: none declared.

Correspondence to: Dr Rosalie E Ferner, Department of Clinical Neurosciences, 2nd floor Hodgkin Building, Guy's, King's and St. Thomas' School of Medicine, London Bridge, London SE1 1UL, UK; rosalie.ferner@kcl.ac.uk

Revised version received 21 May 2004

Accepted for publication 26 May 2004

\section{REFERENCES}

1 Huson SM, Harper PS, Compston DAS. Von Recklinghausen neurofibromatosis: a clinical and population study in South East Wales. Brain 1988;111:1355-81.

2 Ferner RE. Medical complications in neurofibromatosis 1. In: Upadhyaya M, Cooper DN, eds. Neurofibromatosis 1: from genotype to phenotype. BIOS: Oxford, 1998:21-2.

3 Thomas PK, King RH, Chiang TR, Scaravilli F, Sharma AK, Downie AW. Neurofibromatous neuropathy. Muscle Nerve 1990;13:93-101.

4 Evans DGR, Huson SM, Donnai D, Neary W, Blair V, Teare D, Newton V, Strachan T, Ramsden R, Harris R. A genetic study of type 2 neurofibromatosis in the United Kingdom: prevalence, mutation, rate, fitness and confirmation of maternal transmission effect on severity. J Med Genet 1992;29:841-6.

5 Bosch EP, Murphy MJ, Cancilla PA. Peripheral neurofibromatosis and peroneal muscular atrophy. Neurology 1981;31:1408-14.

6 Ohnishi A, Nada O. Ultrastructure of the onion bulb-like lamellated structure observed in the sural nerve in a case of von Recklinghausen's disease. Acta Neuropathol (Berl) 1972;20:258-63.

7 Kilpatrick TJ, Hiorth RJ, Gonzales MF. A case of neurofibromatosis 2 presenting with a mononeuritis multiplex. J Neurol Neurosurg Psychiatry 1992;55:391-3

8 Sperfeld AD, Hein C, Schroder JM, Ludolph AC, Hanemann CO. Occurrence and characterisation of nerve involvement in neurofibromatosis type 2. Brain 2002; 125:996-1004

9 Neurofibromatosis. Conference Statement. National Institutes of Health Consensus Development Conference. Arch Neurol 1988;45:575-8.

10 Gabriel CM, Howard R, Kinsella N, Lucas S, McColl I, Saldanha G, Hall SM, Hughes RAC. Prospective study of the usefulness of sural nerve biopsy. J Neurol Neurosurg Psychiatry 2000;68:442-6.

11 Terenghi G. Peripheral nerve regeneration and neurotrophic factors. J Ana 1999:194:1-14.

12 Ferner RE, Gutmann DH. International consensus statement on the management of malignant peripheral nerve sheath fumours in neurofibromatosis 1. Cancer Res 2002;62:1573-7.

13 Easton DE, Ponder MA, Huson SM, Ponder BA. An analysis of variation in expression of neurofibromatosis type 1 (NF1): evidence of modifying genes. Am J Hum Genet 1993;53:305-13.
14 Stefansson K, Wollmann R, Jerkovic M. S-100 protein in soft tissue tumours derived from Schwann cells and melanocytes. Am J Pathol 1982;106:261-8.

15 Hirose T, Sano T, Hizawa K. Ultrastructural localisation of S-100 protein in neurofibroma. Acta Neuropathol (Berl) 1986;69:103-10.

16 Ushigome S, Takakuwa T, Hyuga M, Tadokoro M, Shinagawa T. Perineurial cell tumour and the significance of the perineurial cells in neurofibroma. Acta Pathol Japan 1986;36:973-87.

17 Peltonen J, Jaakkola S, Lebwohl M, Renvall S, Risteli L, Virtanen I, Uitto J. Cellular differentiation and expression of matrix genes in type 1 neurofibromatosis. Lab Invest 1988;59:760-71.

18 Peltonen J, Foidart JM, Aho HJ. Type IV and V collagens in von Recklinghausen's neurofibromatosis. An immunohistochemical and electrophoretical study. Virchows Arch B Cell Pathol Mol Pathol 1984;47:291-301.

19 Kaila T, Penttinen R, Peltonen J. Cultured neurofibromatosis tumour fibroblasts lack beta-adrenergic receptors. Neurofibromatosis 1988;1:37-42.

20 Kluwe L, Friedrich RE, Mautner VF. Loss of NF1 allele in Schwann cells but not in fibroblasts derived from an NF1-associated neurofibroma. Genes Chromosomes Cancer 1999;24:283-5.

21 Rutkowski JL, Wu K, Gutmann DH, Boyer PJ, Legius E. Genetic and cellular defects contributing to benign tumour formation in neurofibromatosis type 1. Hum Mol Genet 2000;12:1059-66.

22 Serra E, Rosenbaum T, Winner U, Aledo R, Ars E, Estivill X, Lenard H, Lazaro C. Schwann cells harbour the somatic NF1 mutation in neurofibromas: evidence of two different Schwann cell subpopulations. Hum Mol Genet 2000;9:3055-64.

23 Bunge MB. Schwann cell regulation of extracellular matrix biosynthesis and assembly. In: Dyck PJ, Thomas PK, Griffin JW, Low PA, Poduslo JF, eds. Peripheral neuropathy. Philadelphia, PA: WB Saunders, 1993:299-316.

24 Arroyo EJ, Scherer SS. On the molecular architecture of myelinated fibres. Histochem Cell Biol 2000;1 13:1-18.

25 Bunge MB, Wood PM, Tynan LB, Bates ML, Sanes JR. Perineurium originates from fibroblasts: demonstration in vitro with a retroviral marker. Science 1989;243:229-31.

26 Obremski VJ, Wood PM, Bunge MB. Fibroblasts promote Schwann cell basal lamina deposition and elongation in the absence of neurons in culture. Dev Biol 1993;160:119-34.

27 Mirsky R, Parmentier E, McMahon AP, Jessen KR. Schwann cell-derived desert hedgehog signals nerve sheath formation. Ann NY Acad Sci 1999;883:196-202.

28 Parmentier E, Lynn B, Lawson D, Turmaine M, Namini SS, Chakrabarti L, McMahon A, Jessen K, Mirsky R. Schwann cell-derived desert hedgehog controls the development of the peripheral nerve sheath. Neuron 1999;23:713-24.

29 Endo H, Utani A, Masumaoto F, Kusoki T, Yoshimoto S, Ichinose M, Shinkai $\mathrm{H}$. A possible paracrine hedgehog signalling pathway in neurofibromas from patients with neurofibromatosis 1 . Br J Dermato 2002; 148:337-41

30 van Swwieten JC, Koudstaal PJ, Visser MC, Schouten HJ, van Gijn J. Interobserver agreement for the assessment of handicap in stroke patients. Stroke 1988;19:604-7. 